\title{
How healthy are cultivated scallops (Argopecten purpuratus) from Chile? A histopathological survey
}

\author{
¿Qué tan sanos son los ostiones (Argopecten purpuratus) de cultivo en Chile? \\ Un catastro histopatológico \\ Karin B. Lohrmann ${ }^{1}$ \\ ${ }^{1}$ Facultad de Ciencias del Mar, Universidad Católica del Norte, Larrondo 1281, Coquimbo, Chile \\ klohrman@ucn.cl
}

\begin{abstract}
Resumen.- El cultivo del ostión del Norte (Argopecten purpuratus) es una importante actividad económica en la zona centro-norte de Chile, y las enfermedades son una constante preocupación para los cultivadores y la autoridad pesquera. Se realizó un catastro de un año para detectar qué parásitos o posibles patógenos se encuentran presentes en ostiones cultivados en tres localidades: Caldera, Guanaqueros y Tongoy. Se muestrearon 90 ostiones de cada localidad y estación del año. Se extrajeron las partes blandas y se fijaron en fluido de Davidson, procesándose según la técnica histológica de rutina. Se estableció la prevalencia de infección para cada parásito o cambio patológico encontrado. Se muestrearon larvas de tres centros de cultivo, y se procesaron para microscopía electrónica de transmisión. Lo mismo se hizo con glándula digestiva y branquias de los 10 primeros ostiones de cada grupo muestreado para histología. Se encontraron los mismos parásitos y cambios patológicos en ostiones de las tres localidades estudiadas: Inclusiones con organismos tipo rickettsial en epitelio de túbulos de glándula digestiva de adultos y en el velo de una larva, infiltraciones hemocíticas en glándula digestiva y branquias, dos tipos de granulomas de etiología desconocida, en tejido conectivo visceral y del manto, concreciones minerales en células epiteliales renales y el protozoo ciliado ectoparásito Trichodina sp. en branquias. Sin embargo, la prevalencia de todas las condiciones varió considerablemente entre los sitios y/o entre las estaciones del año. Dada la ausencia de mortalidades significativas de los ostiones de cultivo en los tres sitios durante el año de estudio, se concluye que los ostiones de cultivo se encuentran sanos y que las condiciones patológicas encontradas son en general benignas.
\end{abstract}

Palabras clave: Organismos tipo rickettsial, granulomas, Trichodina sp., concreciones renales

\section{Introduction}

Argopecten purpuratus (Lamarck, 1819) the 'Ostión del Norte' (northern scallop) is distributed on the Eastern Pacific coast from Sechura, Perú $\left(6^{\circ} \mathrm{S}\right)$, to Tongoy Bay, Chile $\left(31^{\circ} \mathrm{S}\right)$ (von Brand et al. 2006). The fishery of this bivalve was sustained on natural beds, until the early 1980s, when it started to be exported, and overfishing almost made it disappear. A permanent fishing ban was established in 1986, and is still in force. This scallop then

\begin{abstract}
Scallop (Argopecten purpuratus) cultivation is an important economic activity in the central-northern region of Chile, and diseases are a permanent concern for farmers and fishing authorities. A one year-long survey was undertaken to find out what parasites and putative pathogens are present in cultivated scallops from three locations: Caldera, Guanaqueros and Tongoy. Ninety adult scallops were sampled from each location, on each season of the year. The soft parts were fixed in Davidson's fluid, and processed routinely for histology. The prevalence of infection for each parasite and pathologic condition were assessed. Larvae were sampled from three hatcheries and fixed for transmission electron microscopy. The same was done with digestive gland and gill tissues from the first 10 adults of each group sampled for histology. The same parasites and pathologic conditions were found in scallops from the three locations studied: inclusions of rickettsial-like organisms (RLOs) in epithelial digestive gland tubule cells of adults, and in the velar rim of one larva, haemocyte infiltration in gills and digestive gland, two types of granulomas of unknown aetiology in visceral and mantle connective tissues, mineral concretions in kidney, and the protozoan Trichodina sp., a ciliate ectoparasite, on the gills. However, the prevalences of all conditions varied greatly between the three sites and/or seasons. Based on the absence of significant mortalities among cultured scallops at the three sites during the reported survey year, it is concluded that the surveyed scallops were healthy, and that the pathological conditions reported here are generally benign.
\end{abstract}

Key words: Rickettsial like organisms, granulomas, Trichodina sp., kidney concretions

started to be cultivated in protected bays, mainly Tongoy, Guanaqueros and Caldera using technology based on the Japanese culture methods. It consists on long-lines from which pearl nets (for smaller scallops) and lantern nets (for scallops up to harvest size) are suspended (von Brand et al. 2006).

An important aspect to consider when cultivating any species is disease. Caged culture with high host population densities can undermine the host's immune function, thus 
increasing the risk of disease. High host density also enhances contact, favouring the transmission of parasites, especially of those transmitted horizontally and with direct life cycles (Murray \& Peeler 2005, Novack 2007).

At present there are no OIE (World Animal Health Organisation) listed scallop diseases (OIE 2008 ${ }^{1}$ ). However, some mass mortalities have been reported worldwide for different natural or cultivated scallop species. The sea scallop, Placopecten magellanicus from the east coast of North America, experienced mass mortality in the years 1979 and 1980, being an intracellular rickettsial-like organism the possible cause (Gulka et al. 1983). Also in the east coast, in Florida, almost all the stock of the calico scallop, Argopecten gibbus disappeared due to a protistan parasite of the genus Marteilia (Moyer et al. 1993). A native apicomplexan parasite, Perkinsus qugwadi, caused mortalities of over 90\% in the Japanese scallop Mizuhopecten (Patinopecten) yessoensis cultivated in British Columbia (Bower et al. 1999). In northern China, the cultivated zhikong scallops, Chlamys farreri have suffered from summer mortality since 1996 (Xiao et al. 2005, Belvin et al. 2008).

In Chile there have been no mass mortality events of scallops, and not much information is available on the parasites currently present in either the remaining natural, nor in the cultivated population. Mostly metazoan parasites have been described for Chilean scallops, a larval digenean trematode (Lohrmann et al. $1991^{2}$ ) and a larval cestode were found in cultivated scallops from Coquimbo (Lohrmann \& Smith $1993^{3}$ ) as well as larval cestodes in natural scallops from Antofagasta (Oliva et al. 1986). A comparison of the parasites of natural and cultivated scallops from Tongoy Bay was carried out in 1999, finding that the same parasites were present in both of them, among them Rickettsial-like organisms, Trichodina sp. and granulomas (Lohrmann et al. 2002).

Scallop cultivation is an important economic activity in northern Chile, with a production of 18,781 tons (Sernapesca, 2006 ${ }^{4}$ ), and any disease outbreak could jeopardize this industry. Consequently, knowledge of the parasites and pathogens currently present in the 'healthy' cultivated scallop population, as well as an improved understanding of potentially damaging pathogens is urgently needed. This information, providing baseline data, will place researchers and the industry in a better position to prevent disease outbreaks, or to react with the minimum of delay if epizootics occur.

A one year-long survey was undertaken to find out what parasites and putative pathogens are present in cultivated scallops from three different locations, Caldera, Guanaqueros and Tongoy.

\section{Material and methods}

Ninety adult cultivated scallops were sampled from each location, Caldera $\left(27^{\circ} \mathrm{S}\right)$, Guanaqueros and Tongoy bays $\left(30^{\circ} \mathrm{S}\right)$, Chile (Fig. 1). The samples were taken on January, May, August and December 2002, covering each season of the year. The mean shell heights of sampled scallops ranged from 65 to $82 \mathrm{~mm}$. The soft parts, including digestive gland, adductor muscle, mantle, kidney, gonad and gills, were fixed in Davidson's fluid for $24 \mathrm{~h}$, transferred to $70 \%$ ethanol, and further processed for histology (Shaw \& Battle 1957). Five to $6 \mu \mathrm{m}$ thick paraffin sections were cut, and stained with haematoxylin and eosin. The prevalence, and in some cases also intensity, of infection of each parasite and pathologic condition were assessed.

Larvae were sampled from three hatcheries and fixed for transmission electron microscopy (TEM). No paraffin histology was performed on larvae. Semi-thin epoxy sections were examined for the presence of putative pathogens, and thin sections were examined on the electron microscope, searching mainly for viruses. Forty seven larval samples were processed, most of them coming from normal healthy cultures, and some of them from lots that had some unusual mortalities. The problem with these samples was that most larvae were already dead when they were brought to the laboratory, so not much could be seen. In one case it was possible to obtain larvae of a culture that was starting to show mortality.

Additionally, digestive gland and gill tissues from the first 10 adults of each group sampled for histology were also sampled for TEM. Semi-thin sections from each tissue were examined, and from those where any putative pathogen was detected, thin sections were cut, and viewed on the electron microscope.

\footnotetext{
${ }^{1}$ OIE. 2008. Aquatic Animal Health Code. [on-line] <http://www.oie.int/eng/normes/fcode/A_summry.htm>.

${ }^{2}$ Lohrmann K, Y Smith, S Díaz, M Bustos \& C Cortés. 1991. Presencia de un tremátodo digeneo en Argopecten purpuratus provenientes de poblaciones naturales. IV Congreso Latinoamericano de Ciencias del Mar, Coquimbo, Chile, p. 104.

${ }^{3}$ Lohrmann K \& Y Smith. 1993. Platelmintos parásitos en el Ostión del Norte, Argopecten purpuratus, Lamarck 1819. XIII Jornadas de Ciencias del Mar, p.119.

${ }^{4}$ Sernapesca. 2006. Servicio Nacional de Pesca, Anuario Estadístico. Ministerio de Economía, Fomento y Reconstrucción, Valparaíso. [on-line] $<$ http://www.sernapesca.cl/index.php?option=com_remository\&Itemid=54\&func=select\&id=318>.
} 

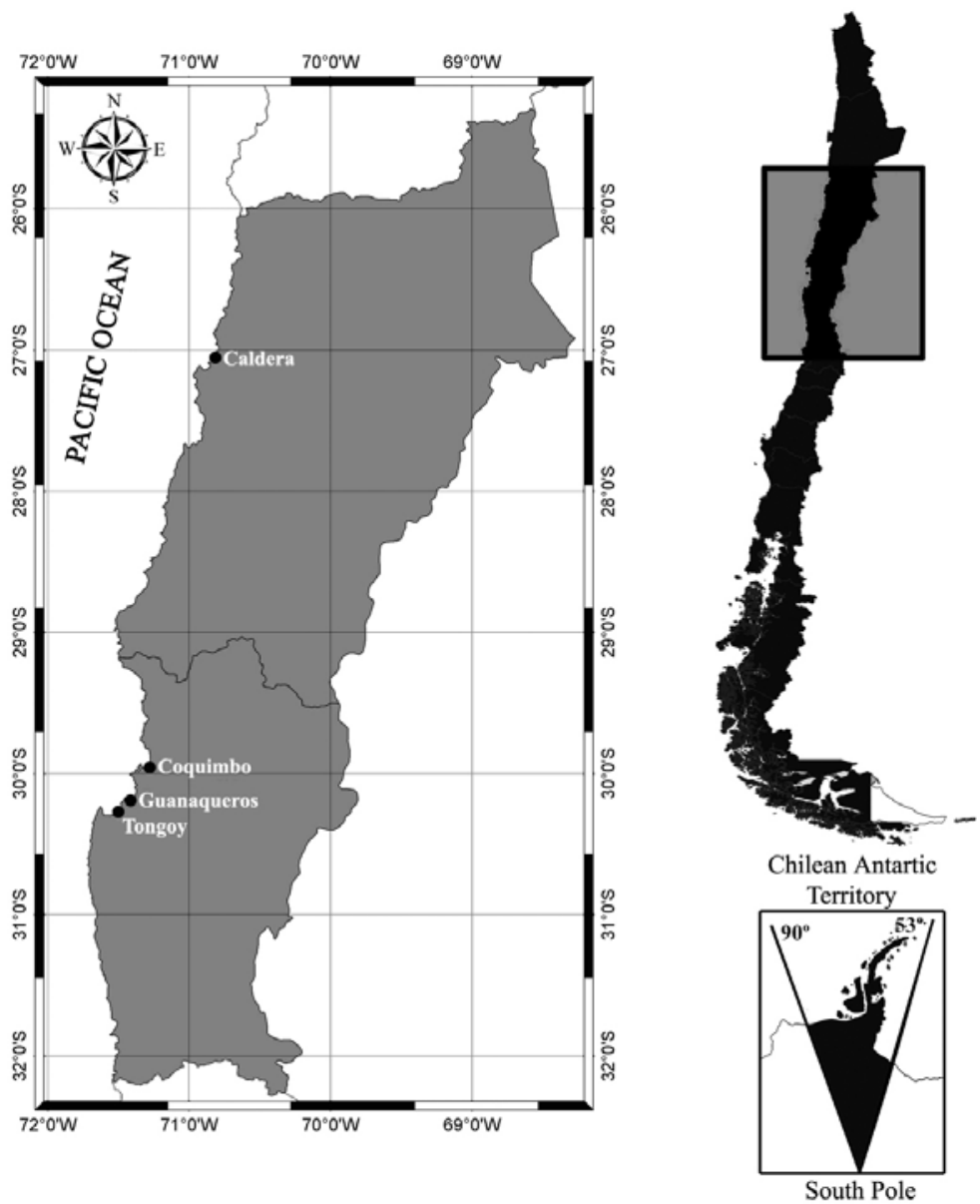

Figure 1

Map of the central-northern region of Chile showing the three sampling sites, Caldera, Guanaqueros and Tongoy

Mapa de la zona centro-norte de Chile, mostrando los tres sitios de muestreo, Caldera, Guanaqueros y Tongoy

TEM: Small, $1 \mathrm{~mm}^{3}$ pieces of digestive gland and gills, and whole larvae were fixed in 3\% glutaraldehyde in 0.2 $\mathrm{M}$ cacodylate buffer with $1.75 \% \mathrm{NaCl}$, for two hours at room temperature. Tissues were washed three times in $0.2 \mathrm{M}$ cacodylate buffer with $1.75 \% \mathrm{NaCl}$, and post-fixed for one hour in $1 \%$ osmium tetroxide in the same buffer. After washing three times with buffer, they were rinsed twice in distilled water, stained for 15 min with $2 \%$ aqueous uranyl acetate, dehydrated in ethanol, washed in acetone, and embedded in Epon 812. Semi-thin sections, $1 \mu \mathrm{m}$ thick, were cut on a Reichert Ultracut S microtome, and stained with toluidine blue. Ninety-nanometer thin sections were cut with a diamond knife, collected on copper grids, and stained with aqueous uranyl acetate and lead citrate. The sections were viewed with a Zeiss EM900 electron microscope at $50 \mathrm{kV}$, and photographs were taken.
Decalcification of larvae: Larvae were fixed and processed as explained above for the tissue pieces, up to $70 \%$ ethanol. They were then washed for $10 \mathrm{~min}$ in 0.2 $\mathrm{M}$ cacodylate buffer and placed in 5\% EDTA in the same buffer for 16 to 18 hours. They were washed twice in 0.2 $\mathrm{M}$ cacodylate buffer, dehydrated in ethanol, acetone, and embedded in Epon 812.

For scanning electron microscopy (SEM), sections from selected paraffin histological blocks were cut at 10 $\mu \mathrm{m}$, and mounted on coverslips. Sections were de-waxed in three changes of xylene, passed through three changes of $100 \%$ ethanol and critical point dried using $\mathrm{CO}_{2}$ (Lohrmann et al. 2002). The coverslips were mounted on bronze stubs and ion sputtered with gold. The sections were viewed and photographed using a JEOL TS 300 microscope. 
Histological slides and semi-thin epoxy sections were analysed using a Nikon E600 Eclipse microscope. The prevalence (percentage of scallops with at least one parasite or pathologic condition) of each parasite or potential pathogen was assessed for scallops from the three sites on each season of the year.

\section{Results}

The same parasites and non-specific pathologic conditions were found among adult scallops from the three locations studied, and they are shown in Figs. 2, 3, 4 and 5. The prevalence of each of the parasites and pathological conditions is presented for the four sampling months for scallops at each locality, in Table 1 for Caldera, Table 2 for Guanaqueros, and Table 3 for Tongoy.

\section{Parasites}

The parasites detected were: two rickettsial-like organisms (RLOs), one of these in digestive gland epithelia of adults, and the other one in the velar epithelium of larvae. One ciliate ectoparasite, Trichodina sp., was found on the gills of adult scallops.
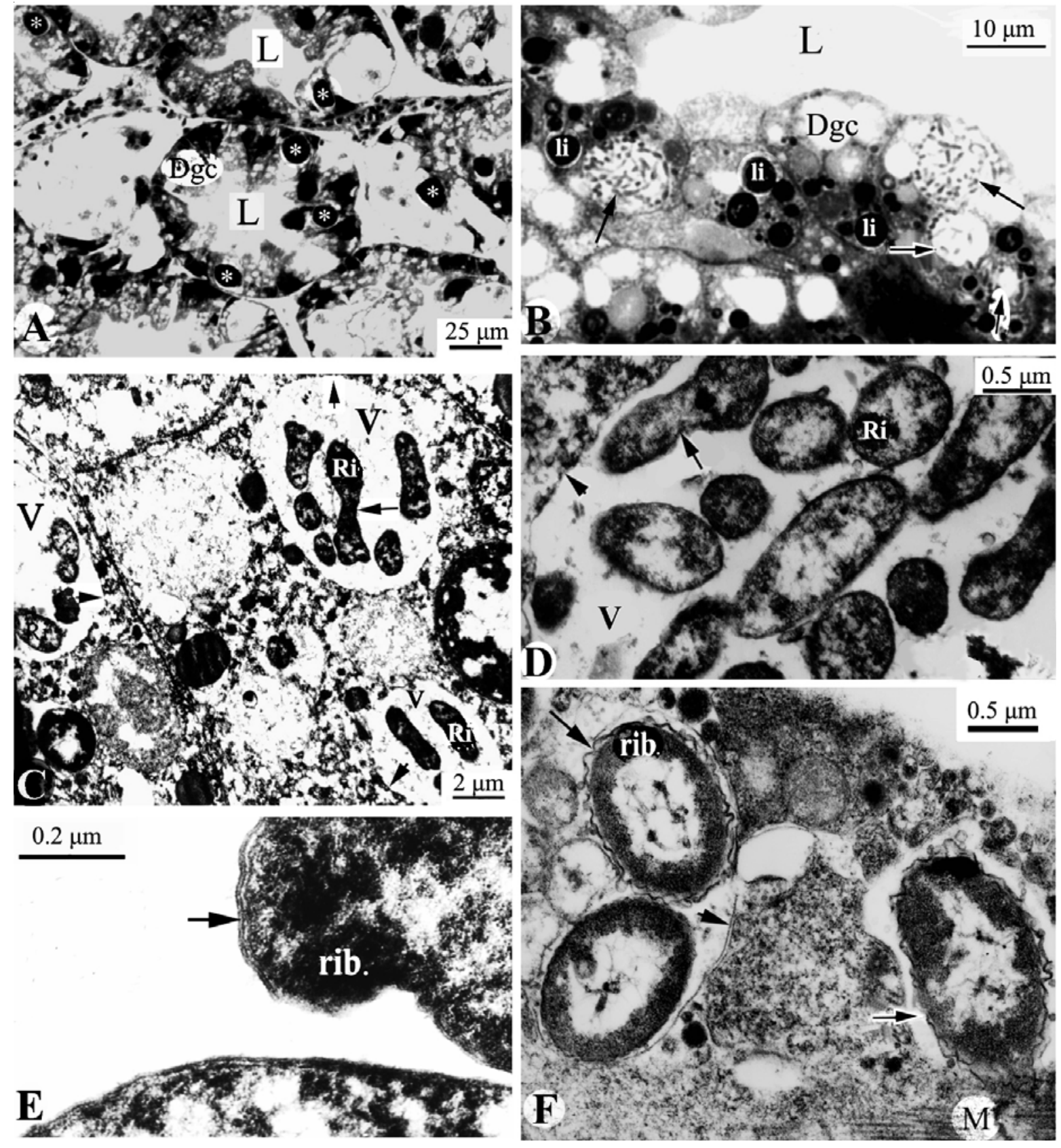
Figure 2

Rickettsial-like organisms (RLOs) in adult Argopecten purpuratus. a. Light microscope photograph showing digestive gland of $A$. purpuratus with basophilic RLO inclusions $\left(^{*}\right)$ in the cells of the digestive gland tubule epithelium. Dgc: digestive gland epithelial cell; L: lumen of digestive gland tubule. Stain: Hematoxylin and Eosin (H \& E); b. Semi-thin epoxy section of part of a digestive tubule of $A$. purpuratus. Arrows point to RLO inclusions within digestive gland epithelial cells (Dgc). Lipid inclusions (li), not visible in paraffin histology slides, have been preserved with osmium tetroxide used for transmission electron microscope (TEM) tissue preparation. L: lumen of digestive gland tubule. Stain: Toluidine blue; c, d \& e. Transmission electron microscope (TEM) images of digestive gland RLOs (Ri) contained within a vacuole (V). Fig. 2c shows one entire vacuole, and part of two smaller vacuoles, with few microorganisms in them. Fig. 2d shows part of one large crowded vacuole. The arrowheads in Fig. 2c and d point to the membrane of the vacuole, the arrows to dividing bacteria. These show the typical «mottled» appearance of RLOs with an electron-dense peripheral arrangement of ribosomes (rib. in Fig. 2e), and an electron opaque central region, where DNA is located. The double membrane typical of RLOs can be clearly observed in Fig. 2e (arrow): $f$. TEM image of the velar rim of a larva of $A$. purpuratus, showing two vacuoles containing RLOs. In one vacuole two organisms are contained, arrowhead points to vacuole membrane. These RLOs are different from those found in digestive gland, the outer membrane is rippled (arrows), and the ribosomes (rib.) are more electron dense. On the lower right part of the photograph, a small part of a velar muscle $(\mathrm{M})$ can be seen

Organismos tipo rickettsiales (OTR) en Argopecten purpuratus. a. Fotografía de microscopía de luz mostrando glándula digestiva de $A$. purpuratus con inclusiones basofilicas de OTRs $(*)$ en las células del epitelio del túbulo de la glándula digestiva. Dgc: célula epitelial de la glándula digestiva; L: lumen del túbulo de la glándula digestiva. Tinción: Hematoxilina y eosina (H \& E); b. Corte semi-fino de parte de un túbulo digestivo de $A$. purpuratus. Las inclusiones de OTR contenidas en células epiteliales de la glándula digestiva (Dgc) son marcadas con flechas. Se observan inclusiones de lípido (li), no visibles en histología, las que se preservaron con el tetróxido de osmio usado en la preparación del tejido para microscopía electrónica de transmisión (MET). Tinción: Azul de toluidina; c, d y e. Imágenes de microscopía electrónica de transmisión (MET) de OTRs (Ri) en glándula digestiva contenidas en una vacuola (V). La Fig. 2c muestra una vacuola completa, y parte de dos vacuolas pequeñas, con pocos organismos en su interior. La Fig. $2 \mathrm{~d}$ muestra parte de una vacuola grande con numerosas rickettsiales. La punta de flecha en la Fig. $2 \mathrm{c}$ y d indica la membrana de la vacuola, y las flechas apuntan a bacterias que se están dividiendo. Éstas muestran el típico arreglo periférico de ribosomas (rib. en Fig. 2e) electro densos, y una región central opaca a los electrones, donde se ubica el ADN. La doble membrana típica de OTRs puede ser observada

claramente en la Fig. 2e (flecha); f. Imagen al MET del borde del velo de una larva de A. purpuratus, mostrando dos vacuolas con OTRs. Una de ellas contiene dos organismos, la punta de flecha señala la membrana de la vacuola. Estas OTRs son diferentes de aquellas encontradas en glándula digestiva, la membrana externa es rizada (flechas), y los ribosomas (rib.) son más electro densos. En la parte derecha inferior se puede observar una pequeña parte de un músculo (M) velar

\section{Rickettsial-like organisms (RLOs)}

RLOs in adult scallops: RLOs were detected in cells of the digestive gland terminal tubules in the form of spherical basophilic inclusions (Fig. 2a). In semi-thin sections small, rod like and ovoid bodies could be distinguished within each of these inclusions (Fig. 2b). Each inclusion was surrounded by a thin membrane, separating the RLOs from the cytoplasm of the host cell (Fig. 2c, d). The size of the inclusions was variable, ranging from 10 to $20 \mu \mathrm{m}$ as measured from the light microscope photographs from histological and semi-thin sections. However, with TEM, smaller inclusions, measuring 5-7 $\mu \mathrm{m}$, with only few RLOs in their interior, were also seen (Fig. 2c). Longitudinal and transversal sections of the rod like RLOs could be observed by TEM, some organisms seemed to be dividing (Fig. 2c, d). They measured $0.6-0.74 \mu \mathrm{m}$ in width, and 1.15 to $2.1 \mu \mathrm{m}$ in length. Each organism was surrounded by a smooth double membrane (Fig. 2e). Internally they showed a 'mottled' appearance, more granular at the periphery, probably corresponding to ribosomes intermixed with tentative DNA filaments (Fig. 2d, e).

RLOs prevalences among scallops fluctuated greatly between sites and seasons, not showing clear or spatial patterns, and ranging from $0 \%$ (Tongoy, summer and winter) to $57 \%$ (Guanaqueros, fall). In Caldera RLOs were present during all seasons, ranging from 28 to $39 \%$ (Tables $1,2$ and 3$)$.

RLOs in larvae: Thin sections were cut from each larva, since the aim was to search for viral particles. RLOs were detected in the velar rim of one larva, in small, membranous inclusions harbouring one or two organisms that measured 1.0 to $1.75 \mu \mathrm{m}$ (Fig. 2f). They were surrounded by a double membrane, the outer one being rippled. The cytoplasm was electron-dense in the periphery, with abundant ribosomes, and showed a clearer central region, with filaments that probably correspond to DNA. The one larva where these RLOs were observed came from a culture batch whose growth was stunted. No viral particles were seen in any of the larvae examined. 

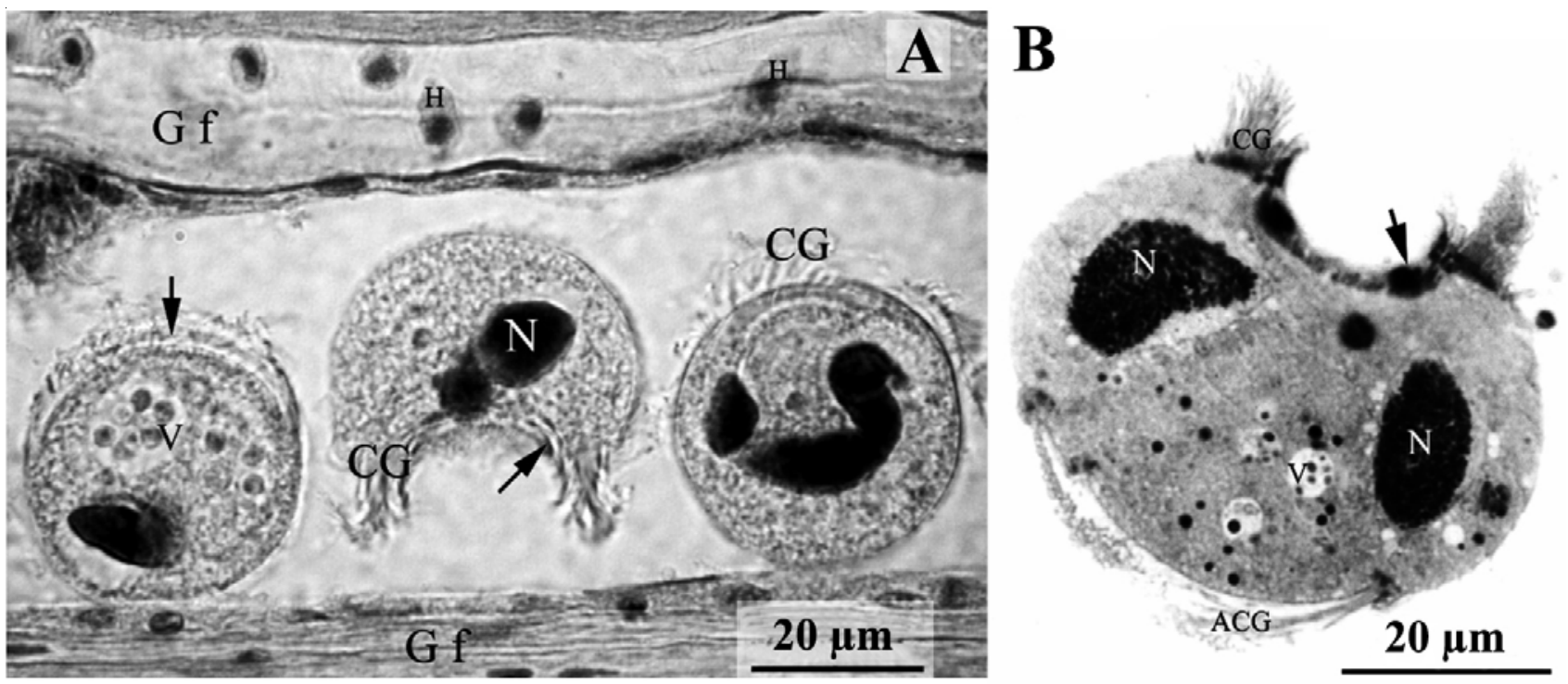

Figure 3

Trichodina sp. in Argopecten purpuratus. a. Light micrograph of three Trichodina sp. individuals in different planes of section. The ciliary girdle (CG) surrounds the oral disc, the denticles are marked by arrows. The nucleous (N) is horse-shoe shaped, and vacuoles (V) containing food can be distinguished in the cytoplasm. The ciliates are loosely placed between two gill filaments (Gf), inside the upper gill filament some hemocytes (H) can be observed. Stain: H \& E; b. Semi-thin section of Trichodina sp. Part of the horse-shoe shaped nucleous $(\mathrm{N})$ with strings of condensed chromatin can be observed. In the cytoplasm some vacuoles with food can be seen. The denticles are indicated by an arrow, the ciliary girdle (CG) surrounds the oral disc. Part of the adoral ciliary girdle (ACG) can also be seen. Stain: Toluidine blue

Trichodina sp. en Argopecten purpuratus. a. Fotografía en microscopía de luz de tres ejemplares de Trichodina sp. en diferentes planos de corte. El cinturón ciliar rodea al disco oral, los dentículos se señalan con flechas. El núcleo $(\mathrm{N})$ tiene forma de herradura y en el citoplasma se distinguen vacuolas $(\mathrm{V})$ con alimento. Los ciliados se encuentran laxamente ubicados entre dos filamentos branquiales (Gf), en el interior del filamento branquial superior se observan algunos hemocitos (H). Tinción: H \& E; b. Corte semi-fino de Trichodina sp. Se observa parte del núcleo $(\mathrm{N})$ en forma de herradura, con cromatina condensada en gruesos cordones. En el citoplasma hay vacuolas (V) con alimento. Los dentículos están señalados por una flecha, el cinturón ciliar (CG) rodea el disco oral. Se observa parte del cinturón ciliar adoral (ACG). Tinción: Azul de toluidina

\section{Ciliate}

The ectoparasitic ciliate Trichodina sp. was detected on the gills of adult A. purpuratus (Fig. 3a). This ciliate was dome shaped, with a characteristic, horseshoe-shaped macronucleus. The oral region was surrounded by a ciliated spiral band, and the basal disc by a ciliary girdle (Fig. 3a, b). This protozoan was loosely attached to the gills, and did not elicit any host response (Fig. 3a).

The prevalence of Trichodina sp. infestations among scallops was lowest in Caldera, (0\% to 14\%), and highest in Tongoy, ranging from $87 \%$ to $97 \%$ during all seasons. In Guanaqueros the prevalence fluctuated greatly, from $6 \%$ to $91 \%$ (Tables 1,2 and 3 ).

\section{Inflammatory and non-specific pathologic conditions}

Two different types of granulomas were observed, type I in visceral connective tissues, and type II in mantle connective tissues. Also inflammatory processes could be seen, evident through infiltration with haemocytes in gills and digestive gland. Finally, kidney mineral concretions were recorded.

\section{Granulomas}

Some degrading cellular material was surrounded by fibroblast-like looking cells, forming small 'nests', which gathered together with more lesions of the same kind, forming a granuloma. No causative agent for these granulomas could be discerned in paraffin histological sections, nor in thick sections viewed with SEM. Two different kinds of granulomas could be distinguished, based on location, the presence or absence of ceroid (brown pigment), and their size. Two different kinds of granulomas could be distinguished, based on location, the presence or absence of ceroid (brown pigment), and their size: 


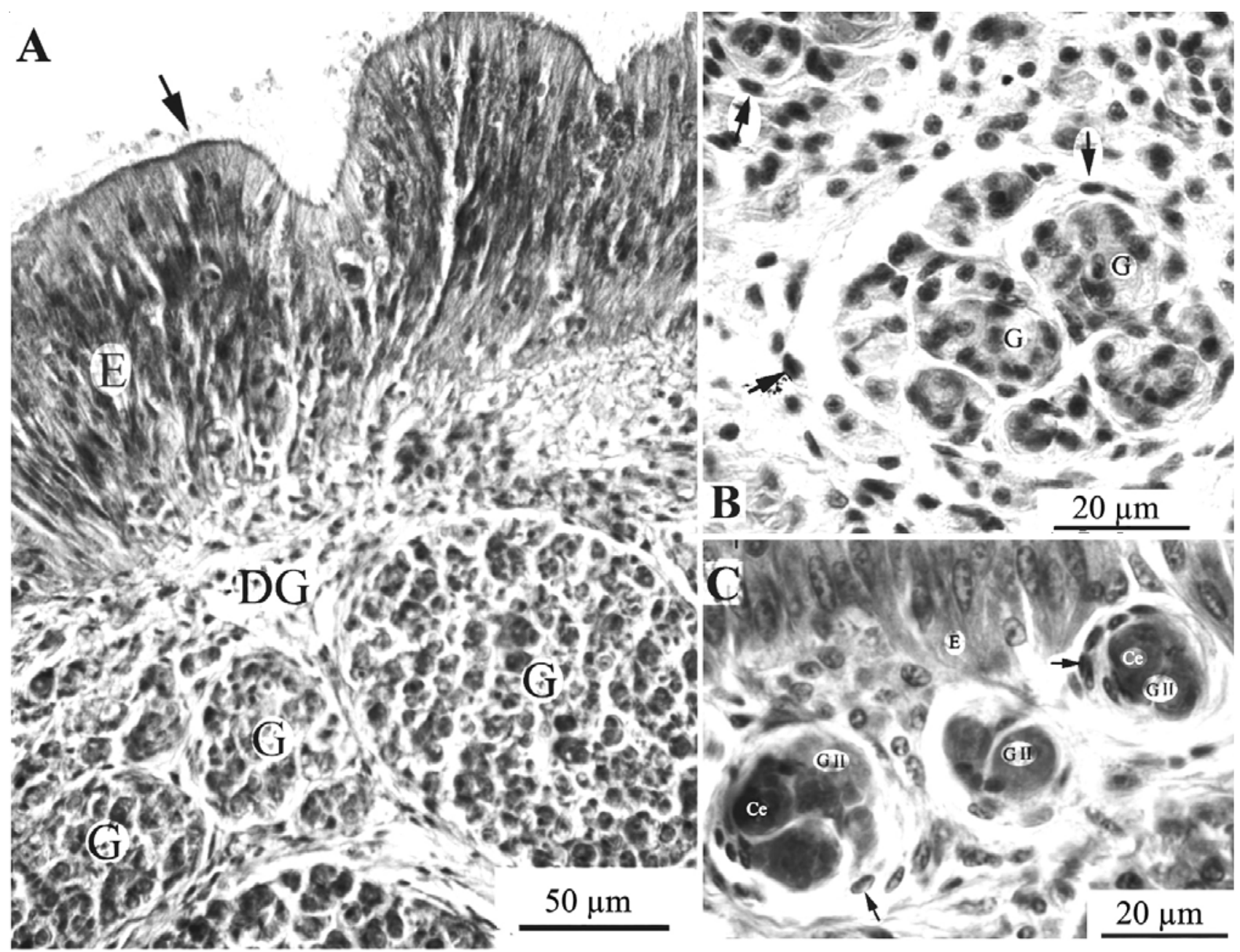

Figure 4

Granulomas in Argopecten purpuratus. a. Type I granuloma in digestive gland (DG). Various granulomas (G) are located below the stomach epithelium (E). Arrow points to cilia. Stain: H \& E; b. Type I granulomas (G) with higher magnification. The arrows point to flattened fibroblast-like cells surrounding unidentified cells. Stain: H \& E; c. Type II granulomas (G II) with ceroid (Ce). Arrows point to fibroblast-like cells surrounding the granuloma. E: Mantle epithelium. Stain: H \& $\mathrm{E}$

Granulomas en Argopecten purpuratus. a. Granuloma tipo I en glándula digestiva (DG). Varios granulomas (G) se encuentran ubicados por debajo del epitelio estomacal (E). La flecha indica los cilios. Tinción: H \& E; b. Granulomas (G) tipo I con mayor aumento. Las flechas indican células aplanadas (tipo fibroblastos) que rodean a células no identificables. Tinción: H \& E; c. Granulomas (G II) tipo II con ceroide (Ce). Las flechas apuntan a células aplanadas tipo fibroblastos rodeando a estos granulomas. E: Epitelio del manto. Tinción: H \& E

Type I granuloma: present in visceral connective tissues underneath the epithelium of stomach or secondary ducts. They showed a wide size range, from very small ones (7-14 $\mu \mathrm{m})$ up to very large ones (90-148 $\mu \mathrm{m})$, which appeared to correspond to the coalescence of many small granulomas. Some of the lesions were also observed in the digestive epithelia, suggesting their transport out of the scallop into the lumen of the stomach or the secondary digestive gland tubules (Fig. 4a, b). The prevalences ranging from $0 \%$ to $6 \%$ among scallops at all sites and during all seasons (Tables 1, 2 and 3).

Type II granuloma: present predominantly in connective tissues of the mantle margin, on the fold facing the shell. Their size ranged from 23 to $77 \mu \mathrm{m}$, and they all contained abundant ceroid, which made the detection of any kind of parasite more difficult than in type I granuloma. Some of these granulomas could be seen in 


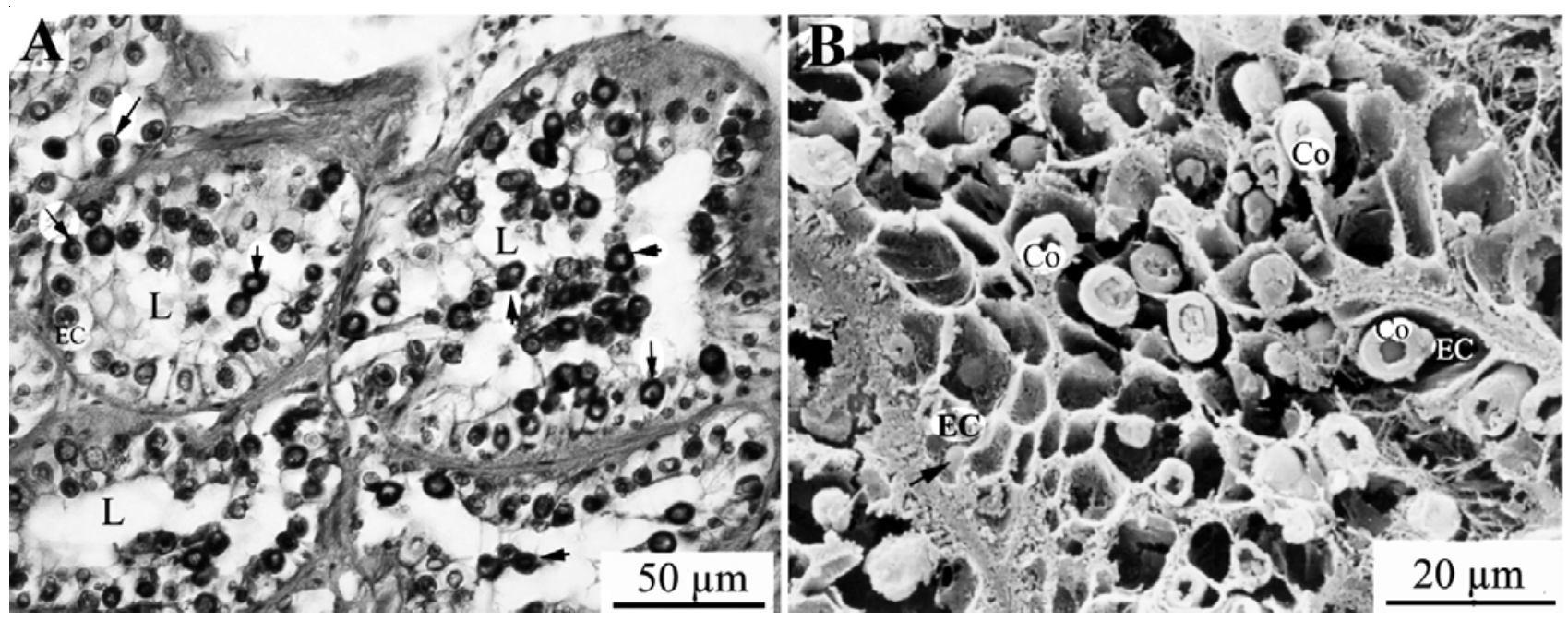

Figure 5

Kidney (nephridial) concretions in Argopecten purpuratus. a. Nephridium with numerous apparent mineral concretions located both intracellularly (arrows) and extracellularly (arrowheads). The concretions show irregularly concentric layers, with a lighter central core. Stain: H \&E; b. Scanning electron microscopy image of a kidney histological section with apparent mineral concretions (Co). The multilayered structure becomes evident. The epithelial cells (EC) look empty, except for some concretions. L: lumen of nephridial tubule

Concreciones renales (nefridiales) en Argopecten purpuratus. a. Nefridio con numerosas concreciones aparentemente minerales ubicadas tanto intracelular (flechas) como extracelularmente (flechas cortas). Las concreciones muestran capas irregularmente concéntricas, con un centro claro. Tinción: H \& E; b. Imagen de un corte histológico de nefridio con concreciones aparentemente minerales (Co) visto en microscopía electrónica de barrido. La estructura multicapas de éstos se hace evidente. Las células epiteliales se ven vacías, excepto por algunas concreciones. L: lumen de túbulo nefridial

Table 1

Prevalences (\%) of parasites and pathological conditions in adult scallops from Caldera during 2002. Ninety scallops were analyzed each sampling month

Prevalencias (\%) de parásitos y condiciones patológicas en ostiones adultos de Caldera durante el 2002. Se analizaron 90 ostiones por cada mes de muestreo

\begin{tabular}{lrrrr}
\hline \multicolumn{1}{c}{ Caldera } & January & May & August & December \\
\hline Rickettsial like organisms & 35 & 28 & 39 & 37 \\
Trichodina sp. & 14 & 1 & 0 & 0 \\
Type I granuloma & 1 & 0 & 2 & 2 \\
Type II granuloma & 12 & 40 & 43 & 8 \\
Hemocytic infiltration in gills & 3 & 6 & 4 & 1 \\
Hemocytic infiltration in digestive gland & 70 & 6 & 6 & 18 \\
Kidney concretions & 34 & 40 & 77 & 62 \\
\hline
\end{tabular}


Table 2

Prevalences (\%) of parasites and pathological conditions in adult scallops from Guanaqueros during 2002. Ninety scallops were analyzed each sampling month

Prevalencias (\%) de parásitos y condiciones patológicas en ostiones adultos de Guanaqueros durante el 2002. Se analizaron 90 ostiones por cada mes de muestreo

\begin{tabular}{lrrrr}
\hline \multicolumn{1}{c}{ Guanaqueros } & January & May & August & December \\
\hline Rickettsial like organisms & 21 & 57 & 2 & 5 \\
Trichodina sp. & 29 & 6 & 91 & 73 \\
Type I granuloma & 0 & 0 & 6 & 1 \\
Type II granuloma & 5 & 0 & 37 & 8 \\
Hemocytic infiltration in gills & 3 & 3 & 2 & 4 \\
Hemocytic infiltration in digestive gland & 8 & 3 & 6 & 2 \\
Kidney concretions & 16 & 8 & 51 & 58 \\
\hline
\end{tabular}

Table 3

Prevalences (\%) of parasites and pathological conditions in adult scallops from Tongoy during 2002. Ninety scallops were analyzed at each sample month

Prevalencias (\%) de parásitos y condiciones patológicas en ostiones adultos de Tongoy durante el 2002. Se analizaron 90 ostiones por cada mes de muestreo

\begin{tabular}{lrrrr}
\hline \multicolumn{1}{c}{ Tongoy } & January & May & August & December \\
\hline Rickettsial like organisms & 0 & 18 & 0 & 36 \\
Trichodina sp. & 97 & 87 & 93 & 95 \\
Type I granuloma & 0 & 0 & 0 & 4 \\
Type II granuloma & 0 & 1 & 0 & 9 \\
Hemocytic infiltration in gills & 5 & 6 & 9 & 13 \\
Hemocytic infiltration in digestive gland & 2 & 0 & 15 & 3 \\
Kidney concretions & 6 & 16 & 28 & 9 \\
\hline
\end{tabular}

the epithelia, seeming to migrate through them, and could also be found outside the mantle.

Type II granulomas were almost absent during fall, winter, and spring among Tongoy Bay scallops in Tongoy ( $0 \%$ to $1 \%)$, but the prevalence there peaked at $9 \%$ during summer. In Guanaqueros scallops prevalences ranged from $0 \%$ to $37 \%$ and in Caldera scallops showed prevalences from $8 \%$ to $43 \%$. In both Caldera and Guanaqueros bays the highest prevalence occurred in winter (Tables 1, 2 and 3).

\section{Hemocytic infiltrations}

Gill hemocytic infiltrations occurred at very low prevalence in scallops at all three sites, and during all seasons ( $1 \%$ to $13 \%)$. Infiltration in the digestive gland varied from $0 \%$ to $18 \%$, except among Caldera scallops, where its prevalence reached $70 \%$ in summer (Tables 1 , 2 and 3$)$.

\section{Kidney concretions}

Dark brown apparent mineral excretion granules with a light core could be observed in kidney tubules, inside the nephrocytes, and also in the lumina (Fig. 5a). In thick sections viewed with SEM it could be seen that these inclusions had a layered, irregularly concentric organization pattern, with a clear central core (Fig. 5b). Kidney concretions were present among scallops at all three sites during all seasons. The prevalence was highest in Caldera scallops (34\% to $77 \%$ ), in Tongoy scallops it ranged from $6 \%$ to $28 \%$, and in Guanaqueros scallops it was $8 \%$ to $58 \%$. The highest prevalences at each site occurred in winter (Tables 1, 2 and 3). 


\section{Discussion}

Although the same parasites and pathologic conditions were detected among scallops at the three locations studied, large differences in prevalences between sites, and seasons were found.

In scallops, RLOs have been described as basophilic inclusion bodies in the gills of Placopecten magellanicus (Gulka et al. 1983); Argopecten irradians (Leibovitz et al. 1984, Karlsson 1991), Patinopecten yessoensis (Elston 1986) and Pecten maximus (LeGall et al. 1988, 1991). They have also been found in the kidney of Argopecten irradians (Morrison \& Shum 1983, McGladdery et al. 1993) as well as in the digestive gland (McGladdery et al. 1993). In New Zealand, RLOs were found in the digestive tissue from Pecten novaezelandiae and Chlamys delicatula (Hine \& Diggles 2002).

It is important to point out that the RLO inclusions detected in one of the larval samples were not seen in the semi-thin section, probably because of their very small size, with only one or two cells inside. Something similar happened with RLO inclusions from digestive glands in adults. The larger inclusions were detected in histological sections, however, when examining with TEM some smaller inclusions, with only few RLOs inside, which had not been seen in the semi-thin sections, were detected. This kind of situation was reported by Hine \& Diggles (2002) in digestive gland of the scallop Pecten novaezelandiae, in association with some mortality events. With histology no RLOs were detected, but with TEM 117 out of 127 scallops evidenced these RLOs. There is an additional reason for not detecting them with light microscopy, they lie directly in the cytoplasm of the host cell, not forming inclusions, and their size is also smaller. However, a small inclusion with few RLOs, as those found in this study, could be equivalent to this situation. For cost reasons examining all the digestive gland resin blocks with TEM was not possible but hopefully, it could be done in the future. This is especially important in regard to larvae, which present the most vulnerable life stage in the development of bivalves. In hatcheries there are unexplained mortalities of larval populations, which occur in about three days. Although we specifically looked for viruses as larval pathogens, it could also be possible that RLOs or chlamydialike organisms (CLOs) are involved, as those described by Leibovitz (1989) causing 80 to $100 \%$ mortalities in larval Argopecten irradians could be important pathogens as well. Wang et al. (1998) reported CLOs in A. irradians cultivated in China, and Li \& Wu (2004) found RLOs in the same species, both authors suggesting that either of these bacteria could be the cause of the mass mortalities experienced.

The prevalence of RLOs showed large fluctuations among scallops at two sites, which is difficult to explain, and longer term sampling data would be needed to assess if there is a pattern of infection dynamics. RLOs could be transmitted by broodstock, as suggested by Morrison \& Shum (1982) for A. irradians examined from a quarantine unit in Prince Edward Island, Canada. The scallops were held there for several generations, and all of them had the same CLOs. A vertical, broodstock mediated transmission might also explain the fluctuating pattern of prevalence of RLOs from scallops from Tongoy bay. This would not be a classical vertical transmission with RLOs in gametes, but rather due to a simultaneous liberation of gametes and RLOs during spawning, the gametes through the nephridial pore, and the RLOs through the anus. The zygotes or early embryos could endocytose these RLOs, which would stay single in a vacuole, invisible by light microscopy, until they reproduce, and form a visible inclusion. In a former study (Lohrmann et al. 2002) a prevalence of $41 \%$ was detected in cultivated scallops from Tongoy in January 1999, and in this study, three years later, sampled in the same month, it was $0 \%$. All the scallops came from the same hatchery, so the use of different broodstock may account for these huge differences in prevalence, not the presence of infective particles in the bay's seawater.

Nevertheless, the intensity of the infections was always low, and the RLOs observed in A. purpuratus do not seem to cause any harm, since no host response was observed. These kinds of prokaryotes are common in bivalves, where they usually cause only mild effects, if any (Lauckner 1983). However, a few serious diseases have also been reported, thought to be caused by RLOs, even if the relationship between the presence of RLOs and the mortalities has not been experimentally demonstrated. In 1983, a mass mortality of Placopecten magellanicus occurred in Rhode Island, U.S.A. and a rickettsia-like organism was found in the gills and other tissues of these scallops (Gulka et al. 1983). Mass mortalities due to branchial RLOs have also been reported for Pecten maximus in Brittany, France (LeGall et al. 1988), for the giant clam Hippopus hippopus ((Norton et al. 1993), and for the clam Venerupis rhomboides from Spain (Villalba et al. 1999). More recently another rickettsial-like organism, Candidatus Xenohaliotis californiensis has caused great mortalities in different abalone species in California (Gardner et al. 1995, Altstatt et al. 1996, Friedman et al. 2000, Friedman \& Finley 2003). This pathogen is listed by the World Organisation for Animal Health (OIE 2008 5 ), and also present in cultivated abalones in Chile, therefore on list 2 of high risk diseases for molluscs in our country (Campalans \& Lohrmann 2009, submitted). Being these RLOs potential pathogens, it is important to undertake further studies on their mode of transmission, their effect on scallops of different

${ }^{5}$ OIE. 2008. Aquatic Animal Health Code. [on-line] <http:// www.oie.int/eng/normes/fcode/A_summry.htm>. 
ages, and how their expression is affected by culture conditions such as density, temperature and depth.

The ciliate Trichodina sp. has been reported before from gills of $A$. purpuratus from Tongoy, Chile (Lohrmann et al. 2002). Boussaïd et al. (1999) found heavy infestations with Trichodina sp. in oysters from areas of poor water quality. The gill lamellae were covered with excessive mucus, which could interfere with respiration. For scallops, Trichodina pectenis has been reported in Patinopecten yessoensis from Canada (Bower et al. 1994). The ciliates did not appear to elicit any host response, but they were present in very large numbers in weakened scallops. Trichodina jadranica (Kuidong et al. 1995) and Trichodina sp. have been reported in Chlamys farreri from China (Xiao et al. 2005). A prevalence of up to $67 \%$ was found in scallops during a summer mortality episode, some haemocyte infiltration and gill deformation was observed adjacent to these ciliates (Xiao et al. 2005).

In this study great differences were found in prevalence of infestation with Trichodina sp. between sampling stations. The highest prevalence of Trichodina from Tongoy was in summer and increased compared to the earlier study, from $56 \%$ up to $97 \%$. The intensity of infestation with this ciliate was never high, so it is unlikely that the high prevalence was produced by poor water quality.

Type I granulomas looked exactly the same as the 'swirl' lesions described by McGladdery et al. (1991) produced by what they thought was a Perkinsus species in Argopecten irradians introduced to Canada. The same was found in Aequipecten tehuelchus from Argentina by Cremonte et al. (2005), which also was not a Perkinsus as it did not hybridize with a Perkinsus genus-specific DNA probe. Goggin et al. (1996) and McGladdery et al. (2006) suggested that the lesions of $A$. irradians from Canada could be produced by a thraustochytrid, however, further studies with TEM are necessary.

Type II granulomas, located in the mantle consisted of encapsulated material with ceroid, a common defence mechanism in molluscs, but it was not possible to identify what was causing them. The same kind of lesions have been described by González \& Arenas $(2002,2007)$ in the same scallop species, always associated with mantle retraction. McGladdery et al. (1991) reported ceroid deposition around the 'swirl' lesions in granulomas that look like type I granuloma, however, Cremonte et al. (2005) did no find any ceroid in the same type of lesion.

Some hemocytic infiltrations were observed in digestive gland and in gills. However, their prevalence was rather low, and no data from other years were available for comparison.
Scallop kidneys or nephridia are tubular structures, lined with clear cells, many of which have an apical vacuole with an excretion granule or concretion. These concretions are formed mainly from calcium phosphate and other elements, which vary with species, season, and even between concretions (Bryan 1973, Doyle et al. 1978, Carmichael et al. 1979, Carmichael \& Fowler 1981, Mauri et al. 1990). Several species exposed to trace metals have been shown to increase their concretion production and liberation, such as Argopecten irradians exposed to cadmium (Carmichael \& Fowler 1981), Placopecten magellanicus exposed to copper (Fowler \& Gould 1988) and the pond snail Lymnea stagnalis exposed to aluminium or cadmium (Desouky 2006). It was suggested that the concretions could be a means of heavy metal detoxification, the metals being added by accretion onto the external layers of the concretion. Experimental exposure of the freshwater snail Planorbius corneus to the pesticide pentachlorophenol induced an increased production and release of these concretions (Klobucar et al. 2001). It seems that the stress caused by pollution such as trace metals causes the increase in kidney concretions. Doyle et al. (1978) found abundant concretions in clams (Mercenaria mercenaria) and A. irradians collected from more or less polluted areas; however, they also found them in molluscs from pristine areas. It is concluded that other kinds of stress, such as spawning, or changes in salinity or temperature can also cause increased production and release of kidney concretions.

In this study the highest prevalence of kidney concretions in Argopecten purpuratus was found in August for all sites. In mytilids surveyed from two sites in the UK, the kidneys showed the highest prevalence of similar melanised kidney aggregates in January and February, which is equivalent to August in the southern hemisphere (Bignell et al. 2008). In both cases this could be related to stress caused by food deprivation due to the lack of microalgae. Caldera was the site with the highest August prevalence, and where the prevalence of kidney concretions was highest during all seasons as well. It is not known what caused them; analysis of the trace metal content of concretions from Caldera to be compared with those from Tongoy and Guanaqueros bays is planned.

It can be said that the cultivated scallops surveyed were healthy, since no serious pathogen was detected and no scallop mortalities have been reported at any of the surveyed sites. This study has gathered baseline information on the sanitary status of cultivated scallops, which will be available for comparison with the results of further studies. It is advised to continue monitoring for detecting any new parasite that could become a pathogen for the scallops, and for assessing the effect of 
change of environmental parameters, such as increasing temperature that could turn already known, apparently harmless symbionts, into pathogens.

\section{Acknowledgments}

This research was financed by FDI-CORFO grant PT-10. Many thanks to Fidel Vargas from the TEM Laboratory of Universidad de Valparaíso, for his skillful assistance in TEM. Very special thanks to three anonymous reviewers, whose thorough review with most valuable comments enormously improved this manuscript.

\section{Literature cited}

Altstatt JM, RF Ambrose, JM Engel, PL Haaker, KD Lafferty \& PT Raimondi. 1996. Recent declines of black abalone Haliotis cracherodii on the mainland coast of central California. Marine Ecology Progress Series 142: 185-192.

Belvin S, R Tremblay, M Roussy \& SE McGladdery. 2008. Inoculation experiments to understand mass mortalities in sea scallop, Placopecten magellanicus Journal of Shellfish Research 27(2): 251-260.

Bignell JP, MJ Dodge, SW Feist, B Lyons, PD Martin, NGH Taylor, D Stone, L Travalent \& GD Stentiford. 2008. Mussel histopathology: effects of season, disease and species. Aquatic Biology 2: 1-15.

Boussaïd B, JL Grippari, T Renault, G Tige \& G Dorange. 1999. Trichodina sp. infestation of Crassostrea gigas oysters in Brittany, France. Journal of Invertebrate Pathology 73: 339-342.

Bower SM, SE McGladdery \& IM Price. 1994. Synopsis of infectious diseases and parasites of commercially exploited shellfish. Annual Review of Fish Diseases 4: 1-199.

Bryan GW. 1973. The occurrence and seasonal variation of trace metals in the scallops Pecten maximus (L.) and Chlamys opercularis (L.) Journal of the Marine Biological Association of the United Kingdom 53: 145-166.

Campalans M \& KB Lohrmann. 2009. Health status of cultured molluscs in Chile susceptible to O.I.E. listed diseases. Submitted.

Carmichael NG \& BA Fowler. 1981. Cadmium accumulation and toxicity in the kidney of the bay scallop Argopecten irradians. Marine Biology 65: 35-43.

Carmichael NG, KS Squibb \& BA Fowler. 1979. Metals in the molluscan kidney: a comparison of two closely related bivalve species (Argopecten), using x-ray microanalysis and atomic absorption spectroscopy Journal of the Fisheries Research Board of Canada 36: 1149-1155.

Cremonte F, A Figueras \& EM Burreson. 2005. A histopathological survey of some commercially exploited bivalve molluscs in northern Patagonia, Argentina. Aquaculture 249(1-4): 23-33.
Desouky MMA. 2006. Tissue distribution and subcellular localization of trace metals in the pond snail Lymnea stagnalis with special reference to the role of lysosomal granules in metal sequestration. Aquatic Toxicology 77(2): 143-152.

Doyle LJ, NJ Blake, CC Woo \& P Yevich. 1978. Recent biogenic phosphorite: concretions in mollusk kidneys. Science 199: 1431-1433.

Elston R. 1986. Occurrence of branchial rickettsiales-like infections in two bivalve molluscs, Tapes japonica and Patinopecten yessoensis, with comments on their significance. Journal of Fish Diseases 9: 69-71.

Fowler BA \& E Gould. 1988. Ultrastructural and biochemical studies of intracellular metalo-binding patterns in kidney tubule cells of the scallop Placopecten magellanicus following prolonged exposure to cadmium or copper. Marine Biology 97: 207-216.

Friedman CS \& CA Finley. 2003. Anthropogenic introduction of the etiological agent of withering syndrome into northern California abalone populations via conservation efforts. Canadian Journal of Fisheries and Aquatic Science 60: 1424-1431.

Friedman CS, KB Andree, KA Beauchamp, JD Moore, TT Robbins, JD Shields \& RP Hedrick. 2000. 'Candidatus Xenohaliotis californiensis', a newly described pathogen of abalone, Haliotis spp., along the west coast of North America. International Journal of Systematic and Evolutionary Microbiology 50: 847-855.

Gardner GR, JC Harshbarger, JL Lake, TK Sawyer, KL Price, MD Stephenson, PL Haaker \& HA Togstad. 1995. Association of prokaryotes with symptomatic appearance of withering syndrome in black abalone Haliotis cracherodii. Journal of Invertebrate Pathology 66: 111-120.

Goggin CL, SEMK Whyte \& RJ Cawthorn. 1996. An assessment of lesions in bay scallops Argopecten irradians attributed to Perkinsus karlssoni (Protozoa, Apicomplexa). Diseases of Aquatic Organisms 24: 77-80.

González M \& G Arenas. 2002. Caracterización de la respuesta inmune en el ostión del norte Argopecten purpuratus (Lamarck, 1819) (Mollusca: Bivalvia). Ciencias Marinas 28(3): 247-255.

González M \& G Arenas. 2007. Modificación de los parámetros inmunitarios hemolinfáticos en el ostión del norte (Argopecten purpuratus Lamarck, 1819) afectados por el cuadro de retracción del manto. Investigaciones Marinas 35(1): 3-12.

Gulka G, PW Chang \& KAMarti. 1983. Prokaryotic infection associated with a mass mortality of the sea scallop, Placopecten magellanicus. Journal of Fish Diseases 6: 355 364.

Hine PM \& BK Diggles. 2002. Prokaryote infections in the New Zealand scallops Pecten novaezelandiae and Chlamys delicatula. Diseases of Aquatic Organisms 50: 137-144. 
Karlsson JD. 1991. Parasites of the bay scallop, Argopecten irradians (Lamarck, 1819). World Aquaculture Workshops 1: 180-189.

Klobucar GIV, J Lajtner \& R Erben. 2001. Increase in number and size of kidney concretions as a result of PCP exposure in the freshwater snail Planorbarius corneus (Gastropoda, Pulmonata). Diseases of Aquatic Organisms 44: 149-154.

Kuidong X, L Yanli \& S Weibo. 1995. Morphological studies on Trichodina jadranica Raabe, 1958, a scallop ciliate parasite (Protozoa: Ciliophora: Peritricha). Journal of Ocean University of Qingdao 25(3): 321-326.

Lauckner G. 1983. Diseases of mollusca: Bivalvia. In: Kinne O (ed). Diseases of marine animals, Vol II: 477-961. Biologische Anstalt Helgoland, Hamburg.

LeGall G, D Chagot, E Mialhe \& H Grizel. 1988. Branchial rickettsiales-like infection associated with a mass mortality of the sea scallop Pecten maximus. Diseases of Aquatic Organisms 4: 229-232.

LeGall G, E Mialhe, D Chagot \& H Grizel. 1991 Epizootiological study of rickettsiosis of the Saint-Jacques scallop Pecten maximus. Diseases of Aquatic Organisms 10: $139-145$.

Leibovitz L. 1989. Chlamydiosis: a newly reported serious disease of larval and postmetamorphic bay scallops, Argopecten irradians (Lamarck). Journal of Fish Diseases 12: $125-136$

Leibovitz L, EF Schott \& RC Karney. 1984. Diseases of wild, captive and cultured scallops. Journal of the World Mariculture Society 15: 269-283.

Li D \& X Wu. 2004. Purification and biological features of a rickettsia-like prokaryote from the scallop Argopecten irradinas in China. Aquaculture 234: 29-40.

Lohrmann KB, AR Brand \& SW Feist. 2002. Comparison of the parasites and pathogens present in a cultivated and in a wild population of scallops (Argopecten purpuratus Lamarck, 1819) in Tongoy Bay, Chile. Journal of Shellfish Research 21(2): 557-561.

Mauri M, E Orlando, M Nigro \& F Regoli. 1990. Heavy metals in the Antarctic scallop Admusium colbecki. Marine Ecology Progress Series 67: 27-33.

McGladdery SE, SM Bower \& RG Getchell. 2006. Diseases and parasites of scallops. In: Shumway SE \& GJ Parsons (eds), Scallops: Biology, ecology and aquaculture. Developments in Aquaculture and Fisheries Science 35: 595-650. Elsevier, Amsterdam.

McGladdery SE, BC Bradford \& DJ Scarratt. 1993. Investigations into the transmission of parasites of the Bay scallop Argopecten irradians (Lamarck, 1819) during quarantine introduction to Canadian waters. Journal of Shellfish Research 12(1): 49-58.
McGladdery SE, RJ Cawthorn \& BC Bradford. 1991. Perkinsus karlssoni n.sp. (Apicomplexa) in bay scallops Argopecten irradians. Diseases of Aquatic Organisms 10: 127-137.

Morrison C \& G Shum. 1982. Chlamydia-like organisms in the digestive diverticula of the bay scallop, Argopecten irradians (Lmk). Journal of Fish Diseases 5: 173-184.

Morrison C \& G Shum. 1983. Rickettsias in the kidney of the bay scallop, Argopecten irradians (Lmk). Journal of Fish Diseases 6: 537-541.

Moyer MA, NJ Blake \& WS Arnold. 1993. An ascetosporan disease causing mass mortality in the Atlantic calico scallop Argopecten gibbus (Linnaeus, 1758). Journal of Shellfish Research 12(2): 305-310.

Murray AG \& EJ Peeler. 2005. A framework for understanding the potential for emerging diseases in aquaculture. Preventive Veterinary Medicine 67: 223-235.

Norton JH, MA Shepherd, MRAbdon-Naguit \& S Lindsay. 1993. Mortalities in the giant clam Hippopus hippopus associated with Rickettsiales-like organisms. Journal of Invertebrate Pathology 62: 207-209.

Novack BF. 2007. Parasitic diseases in marine cage culture An example of experimental evolution of parasites? International Journal for Parasitology 37: 581-588.

Oliva M, H Herrera, J Matulic \& B Severino. 1986. Parasitismo en el Ostión del Norte Chlamys (Argopecten) purpuratus (Lamarck, 1819). Parasitología al Día 10: 8386.

Shaw BL \& HI Battle. 1957. The gross microscopic anatomy of the digestive tract of the oyster Crassostrea virginica (Gmelin). Canadian Journal of Zoology 35: 325-347.

Villalba A, MJ Carballal, C López, A Cabada, L Corral \& C Azevedo. 1999. Branchial rickettsia-like infection associated with clam Venerupis rhomboides mortality. Diseases of Aquatic Organisms 36: 53-60.

Von Brand E, GE Merino, AAbarca \& W Stotz. 2006. Scallop fishery and aquaculture in Chile. In: Shumway SE \& J Parsons (eds). Scallops: Biology, ecology and aquaculture. Developments in Aquaculture and Fisheries Science, Vol. 35: 1293-1311. Elsevier, Amsterdam.

Wang WX, WT Luo, QG Xue, QY Song, JP Zhu, JS Tan, YY Hou \& GX Zou. 1998. Pathological research on Chlamydia-like organisms in the hepatopancreatic gland of the bay scallop, Argopecten irradians (Lamarck). Journal of Ocean University of Qingdao 3: 23-25.

Xiao J, SE Ford, H Yang, G Zhang, F Zhang \& X Guo. 2005. Studies on mass summer mortality of cultures zhikong scallops (Chlamys farreri Jones et Preston) in China. Aquaculture 250: 602-615. 